\title{
PEMANFAATAN TEKNOLOGI INFORMASI DALAM PENINGKATAN PENJUALAN PADA PERUSAHAAN PERCETAKAN EXCELLENT DI SURABAYA
}

\author{
Deograsias Yoseph Yustinianus Ferdinand \\ Program Studi Manajemen \\ Fakultas Ekonomi Universitas Katolik Darma Cendika \\ Jalan Dr. Ir. H. Soekarno 201, Surabaya \\ dyoseph279@gmail.com \\ Jeanne Asteria Wawolangi \\ Program Studi Akuntansi \\ Fakultas Ekonomi Universitas Katolik Darma Cendika \\ Jalan Dr. Ir. H. Soekarno 201, Surabaya \\ jeanneasteria@gmail.com
}

\begin{abstract}
The development of information systems especially in the technological aspects is a challenge and an opportunity for Excellent printing companies. These challenges and opportunities as a stimulation to improve the quality and quantity of sales of printed products such as form of brochures, banners, invitations card, notes, and others. In this case the leadership of the company must be aware that the contribution of systems and information technology can provide maximum benefits for the continuance of the company. Information systems and technology can support the process of selling activities more effectively and optimally, so that company revenue can increase. There needs to be real communication, especially with potential customers so that the sales process can run fluently and continuously, but it must be followed by product innovation.
\end{abstract}

Keywords: printing companies, information technology, sales.

\begin{abstract}
ABSTRAK
Perkembangan sistem informasi terutama pada aspek teknologinya merupakan tantangan sekaligus peluang bagi perusahaan percetakan Excellent. Tantangan dan peluang ini sebagai pendorong untuk meningkatkan kualitas dan kuantitas penjualan produk cetakan berupa brosur, banner, spanduk, undangan, notes, dan lain-lain. Dalam hal ini, pimpinan perusahaan harus sadar bahwa kontribusi sistem dan teknologi informasi dapat memberikan manfaat yang maksimal bagi kelangsungan perusahaan. Sistem dan teknologi informasi dapat menunjang proses aktivitas penjualan lebih efektif dan optimal, sehingga pendapatan
\end{abstract}


perusahaan dapat bertambah. Perlu adanya komunikasi yang riil khususnya dengan konsumen yang potensial agar proses penjualan dapat berjalan lancar dan secara terus menerus, tetapi harus diikuti dengan inovasi produk.

Kata kunci: perusahaan percetakan, teknologi informasi, penjualan.

\section{PENDAHULUAN}

Saat sekarang ini teknologi komunikasi merupakan hal yang penting dalam kehidupan sosial, khususnya bisnis. Penggunaan teknologi baik langsung maupun tidak langsung akan berpengaruh terhadap strategi penentuan harga suatu produk atau jasa (Putranta, 2004: 11). Teknologi dan sistem informasi memungkinkan manajer untuk meningkatkan efisiensi dan produktivitas ke level yang lebih tinggi (Laudon and Laudon, 2002: 43). Teknologi memiliki peran yang krusial dalam peningkatan penjualan pada perusahaan. Teknologi akan memberi kemudahan perusahaan untuk bersaing di pasar. Sistem informasi bertugas untuk mencatat, mengolah, menyimpan data, dan menyediakan informasi, sehingga organisasi dapat mencapai tujuan yang ditetapkan.

Pemrosesan data dalam sistem informasi dapat dilakukan secara manual dan terkomputerisasi. Kedua pilihan ini memiliki keuntungan dan kerugian masing-masing. Dari sisi biaya, dalam jangka pendek sistem informasi lebih murah jika diselenggarakan secara manual. Namun cara ini tentunya akan menghasilkan informasi yang lebih lambat, kurang akurat, serta kurang efektif. Sebaliknya dengan menggunakan teknologi, sistem informasi dapat menghasilkan informasi yang lebih cepat, lebih akurat, dan lebih efektif, meskipun investasi awal (jangka pendek) lebih besar dibandingkan dengan sistem manual. Selain itu, dengan memakai teknologi komputer, sistem penyimpanan data menjadi lebih ringkas dan lebih mudah diakses ketika dibutuhkan.

Dalam skala yang lebih kecil, sistem informasi yang memanfaatkan teknologi komputer juga sangat bermanfaat untuk mengelola order penjualan yang diterima dari konsumen. Sistem informasi terkomputerisasi memungkinkan untuk mengelola pesanan penjualan lebih efektif, efisien, paperless, dan serba otomatis. Di dalam sebuah perusahaan yang menerapkan input atas setiap order penjualan masuk yang terjadi sehari-hari, akan sangat merepotkan bila semuanya dilakukan secara manual (paper based), selain itu sistem penyimpanannya kurang ringkas dan kurang cepat apabila dibutuhkan pada saat-saat tertentu.

Demikian halnya yang terjadi di bisnis percetakan. Peran teknologi informasi sangat dominan dalam menjalankan bisnis dan menjaga keberlangsungan bisnis percetakan. Untuk itu teknologi informasi mempunyai peran dalam strategi bisnis perusahaan. Peranan teknologi informasi dalam industri percetakan bisa sebagai support, enabler, bahkan sebagai business driver. Tentunya dengan pemanfaatan teknologi informasi dalam aktivitas industri tersebut makin meningkatkan daya saing perusahaan percetakan. Perkembangan teknologi terkini mengharuskan perusahaan percetakan menerapkan teknologi informasi secara digital dalam menjalankan usahanya. 


\section{TINJAUAN PUSTAKA}

\section{Sistem Informasi}

Sistem informasi dapat didefinisikan sebagai sebuah penggabungan antara informasi proses produksi, informasi penyimpanan, dan informasi pendistribusian ke dalam sebuah sistem yang akan memberikan masukan yang baik dan berguna bagi pengambil keputusan perusahaan (Laudon and Laudon, 2014: 45).

\section{Data dan Informasi}

Data adalah fakta berupa angka, teks, dokumen, gambar, bagan, dan suara yang mewakili deskripsi verbal tertentu. Data dikumpulkan untuk maksud dokumentasi. Sedangkan informasi dapat didefinisikan sebagai data yang telah diolah (diurutkan, dipadatkan, disaring, dicuplik, dan sebagainya), sehingga memiliki arti dan nilai yang lebih tinggi bagi seorang individu atau kelompok tertentu. Informasi diperlukan untuk membuat keputusan, untuk manajemen organisasi (Parker, 1989). Gambar 1 menunjukkan bagan hubungan antara data, proses, dan informasi.

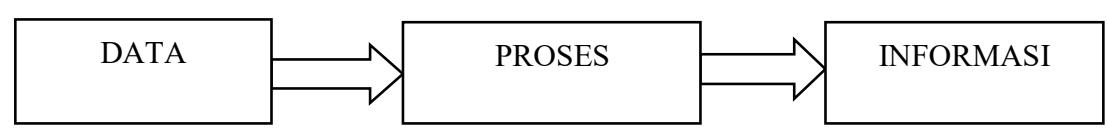

Gambar 1

Bagan Hubungan Data dan Informasi

Agar bermanfaat, informasi harus memiliki kualitas atau karakteristik yang bermutu seperti berikut ini:

\section{Relevan}

Informasi harus bisa menambah pengetahuan atau nilai bagi para pembuat keputusan, dengan cara mengurangi ketidakpastian, menaikkan kemampuan untuk memprediksi, dan sesuai dengan kebutuhan saat ini.

2. Andal

Informasi harus bebas dari kesalahan atau bias dan secara akurat terpercaya menggambarkan kejadian atau aktivitas organisasi.

3. Lengkap

Informasi tidak boleh menghilangkan data penting yang dibutuhkan oleh para pemakai.

4. Tepat Waktu

Informasi harus disajikan pada saat yang tepat untuk mempengaruhi proses pembuatan keputusan.

5. Mudah Dipahami

Disajikan dalam format yang mudah dipahami.

6. Dapat Diverifikasi

Informasi memungkinkan dua orang atau lebih yang kompeten untuk membuat dan menghasilkan informasi yang sama secara bebas/independen (Steinbert, 2003: 12). 


\section{Teknik Dokumentasi}

Dalam menganalisis sebuah sistem, digunakan desain dan teknik dokumentasi sistem, serta hal lain yang terkait dengan sistem itu sendiri. Dokumentasi meliputi bentuk naratif, bagan alir (flowchart), diagram, dan materi tertulis lainnya, yang menjelaskan bagaimana sebuah sistem bekerja. Informasi ini meliputi siapa, apa, kapan, di mana, mengapa, dan bagaimana data dimasukkan, diproses, disimpan, menghasilkan informasi, serta bagaimana pengendalian sistem. Salah satu alat yang sering digunakan untuk mendokumentasikan sistem adalah DFD (Data Flow Diagram) (Hall, 2013). Sebuah DFD secara grafis menjelaskan arus data dalam sebuah organisasi. Teknik ini digunakan untuk mendokumentasi sistem yang digunakan sekarang dan untuk merencanakan serta mendesain sistem yang baru. DFD disusun menggunakan empat simbol utama (Krismiaji, 2015: 68). Simbol diagram arus data seperti terlihat pada Tabel 1.

Tabel 1

Simbol Diagram Arus Data

\begin{tabular}{|c|c|c|}
\hline Simbol & Nama & Penjelasan \\
\hline$\square$ & $\begin{array}{c}\text { Sumber, dan } \\
\text { tujuan data } \\
\longrightarrow\end{array}$ & $\begin{array}{c}\text { Karyawan, dan organisasi yang mengirim data } \\
\text { ke, dan menerima data dari sistem digambarkan } \\
\text { dengan kotak. }\end{array}$ \\
\hline$\square$ & $\begin{array}{c}\text { Proses } \\
\text { transformasi } \\
\text { dari sebuah proses digambarkan dengan anak } \\
\text { panah. }\end{array}$ & $\begin{array}{c}\text { Proses yang mengubah data dari input menjadi } \\
\text { output digambarkan dengan lingkaran. }\end{array}$ \\
\hline & $\begin{array}{c}\text { Penyimpanan } \\
\text { data }\end{array}$ & $\begin{array}{c}\text { Penyimpanan data digambarkan dengan dua } \\
\text { garis horisontal (pararel). }\end{array}$ \\
\hline &
\end{tabular}

Pada dasarnya DFD dapat dirinci lebih lanjut ke dalam jenjang yang lebih rendah, agar dapat diperoleh pemahaman yang lebih rinci dan mendalam tentang sebuah sistem. Dengan demikian, diagram arus data dapat dibagi ke dalam jenjang-jenjang sesuai dengan kebutuhan sistem. Jenjang tertinggi disebut dengan diagram konteks (context diagram) yang menggambarkan ikhtisar paling ringkas dari sebuah sistem. Karena sangat ringkas, maka akan dapat diperoleh gambaran yang utuh mengenai sebuah sistem. Karena sangat ringkas, maka agar dapat diperoleh gambaran yang utuh mengenai sebuah sistem, diagram ini dilengkapi dengan narasi lengkap.

\section{Pengendalian Sistem Informasi Berbasis Komputer}

Pengendalian umum dirancang untuk menjamin bahwa seluruh sistem komputer dapat berfungsi secara optimal dan pengolahan data dapat dilakukan secara lancar sesuai dengan yang direncanakan (Krismiaji, 2015: 243). Pengendalian umum yang akan dibahas pada jurnal ini adalah berkaitan dengan pengendalian akses logis. 
Pada pengendalian akses logis, para pengguna hanya diizinkan mengakses data yang dipercayakan kepada masing-masing pengguna untuk dipakai. Untuk membatasi akses logis, sebuah sistem harus membedakan antara pemakai yang sah dan pemakai yang tidak sah. Di antara cara untuk membatasi akses logis dalam jurnal ini adalah menggunakan password.

Password, kata kunci ini merupakan cara yang paling banyak digunakan. Cara kerja sistem ini adalah pertama pemakai memasukkan kode karyawan, nama karyawan, kode rekening. Kemudian pemakai diminta untuk memasukkan identitas khusus atau password, yaitu serangkaian karakter khusus yang hanya diketahui oleh pemakai yang bersangkutan dan komputer. Selanjutnya, komputer melakukan pencocokkan dengan identitas yang telah terekam dalam komputer. Jika identitas yang dimasukkan cocok, maka dianggap pemakai tersebut merupakan pemakai yang sah dan pemakai tersebut diizinkan untuk meneruskan kegiatannya.

\section{Pengendalian Aplikasi}

Pengendalian aplikasi berhubungan dengan segala hal mengenai aplikasiaplikasi di bagian sistem informasi akuntansi terkomputerisasi. Pengendalian ini berfungsi untuk memberikan jaminan yang cukup bahwa pencatatan, pengolahan, dan pelaporan data telah dilaksanakan dengan benar.

Pengendalian aplikasi mencakup tiga pengendalian, yaitu: pengendalian masukan (input control), pengendalian proses (process control), pengendalian keluaran (output control). Pengendalian aplikasi yang akan dibahas di dalam jurnal ini adalah pengendalian masukan (input control).

Tujuan utama pengendalian aplikasi adalah untuk menjamin akurasi dan validitas input, file, program, output sebuah aplikasi. Jika pengendalian aplikasi lemah, output sistem informasi akan mengandung kesalahan. Output yang mengandung kesalahan ini jika digunakan untuk membuat keputusan, akan menghasilkan keputusan yang tidak tepat (Krismiaji, 2015: 257).

a) Pengendalian masukan

Pengendalian masukan direncanakan untuk memberikan jaminan yang cukup, bahwa data yang diterima untuk diproses oleh sistem EDP (Electronic Data Processing) sudah diotorisasi, diubah bentuk yang dapat dibaca oleh mesin, dan diidentifikasi, serta data itu tidak ada yang hilang, berkurang, bertambah, diduplikasi, atau dapat diubah tanpa izin. Pengendalian masukan termasuk pengawasan yang berhubungan dengan penolakan, koreksi, dan memasukkan kembali data yang sudah dikoreksi. Data masukan yang akan dimasukkan ke dalam komputer dapat melibatkan 3 tahap yaitu data capture (perolehan data), data preparation (penyiapan data), dan data entry (pemasukan data). Pada jurnal ini yang dibahas pengendalian masukan berupa data entry (pemasukan data). Data entry (pemasukan data) merupakan proses membacakan atau memasukkan data ke dalam komputer. Pengendalian pada tahap ini berupa pengecekan terprogram yaitu pengecekan yang telah diprogram di dalam program aplikasi. Pengendalian yang telah ada di pengecekan terprogram dapat berupa: user id dan password. User id merupakan cara pengendalian yang membatasi data entry hanya oleh personal yang sah/berhak saja. 
b) Echo check

Echo check adalah data yang diketikkan pada keyboard untuk dimasukkan ke komputer dan akan ditampilkan (echo) pada layar monitor. Dengan demikian operator dapat membandingkan antara data yang diketikkan dengan data yang seharusnya dimasukkan. Program tersebut dibuat sedemikian rupa dengan memberikan kesempatan pada operator untuk membetulkannya bila data yang diketikkan salah. Kesalahan ini tidak dapat dideteksi oleh komputer, sehingga harus diperiksa oleh operator.

c) Exsistence check

Pengendalian data dilakukan dengan cara membandingkan kode-kode yang dimasukkan dengan daftar kode yang valid dan sudah diprogram, misalnya transaksi penjualan online hanya mempunyai 2 jenis penjualan saja, yaitu dengan kode ' $\mathrm{T}$ ' dan penjualan kredit dengan kode ' $\mathrm{K}$ '. Bila dimasukkan kode selain ' $\mathrm{T}$ ' atau ' $\mathrm{K}$ ', berarti kode tersebut salah. Kesalahan ini dapat dideteksi oleh komputer.

d) Field check

Field data yang dimasukkan diperiksa kebenarannya dengan mencocokkan nilai dari field data tersebut dengan tipe field-nya, apakah bertipe numerik/angka, alphabetik, ataukah tanggal. Tipe field numerik harus diisi dengan data numerik. Bila tidak diisi dengan data numerik berarti salah.

e) Self checking digit check

Hal ini dimaksudkan untuk memeriksa dan mendeteksi kebenaran dari digit data yang dimasukkan. Pengecekan kebenaran ini harus dipergunakan dengan benar, karena operator yang bertugas cenderung melakukan kesalahankesalahan memasukan digit-digit data penjualan. Kesalahan-kesalahan tersebut dapat berupa kelebihan, pemotongan, penulisan, peletakan posisi, kesalahan acak digit, atau karakter. Untuk mendeteksi kesalahan-kesalahan yang dilakukan tersebut dilakukan dengan memberi bobot nilai pada masing-masing posisi digit.

f) Zero-balance check

Jika transaksi penjualan yang dimasukkan merupakan nilai-nilai yang saling mengimbangi, misalnya nilai-nilai debit dan nilai-nilai kredit, maka nilai-nilai tersebut harus seimbang. Zero-balance check akan melakukan pengecekan selisih antara 2 sisi tersebut harus seimbang. Misalnya transaksi jurnal umum yang melibatkan beberapa rekening-rekening debit harus sama dengan total nilai rekening-rekening kredit.

g) Missing data check, yaitu bentuk pengendalian yang menilai isi dari field apakah masih ada field yang kosong pada field-field yang harus diisi.

h) Validation check, yaitu bentuk pengendalian yang membandingkan nilai yang ada dalam field dengan yang sudah diketahui pada master file.

\section{Basis Data}

Secara sederhana database (basis data) dapat diungkapkan sebagai suatu pengorganisasian data dengan bantuan komputer yang memungkinkan data dapat diakses dengan mudah dan cepat. Hal ini tentu saja sangat membantu dalam menyelesaikan tugas pekerjaan sehari-hari yang memerlukan akses data. 
Pengertian akses dapat mencakup perolehan data maupun pemanipulasian data, seperti menambah dan menghapus data (Kadir, 2003: 2).

Basis data dapat didefinisikan sebagai kumpulan field data yang saling berhubungan (berelasi) dan diorganisasi sedemikian rupa agar dapat diakses dengan mudah dan cepat. Basis data bertujuan untuk mengatur data, sehingga diperoleh kemudahan, ketepatan, dan kecepatan dalam pengembalian kembali.

\section{Siklus Penjualan}

Siklus penjualan adalah urutan kegiatan sejak diterimanya pesanan dari pembelian, pengiriman barang, pembuatan faktur penagihan, dan pencatatan penjualan. Prosedur penjualan melibatkan beberapa bagian dalam perusahaan dengan tujuan agar sistem penjualannya dapat diawasi dengan baik. Tujuan sistem penjualan adalah:

1. Mencatat order penjualan dengan cepat dan akurat.

2. Untuk memverifikasi konsumen yang layak menerima kredit.

3. Untuk mengirim produk dan memberikan jasa tepat waktu, sesuai yang dijanjikan kepada konsumen.

4. Untuk membuat tagihan atas produk dan jasa secara tepat waktu dan akurat.

5. Untuk mencatat dan mengelompokkan penerimaan kas secara cepat dan akurat.

6. Untuk mem-posting penjualan dan penerimaan kas ke rekening piutang.

7. Untuk menjaga keamanan produk.

8. Untuk menjaga kas perusahaan.

Data-data yang dibutuhkan dan dihasilkan dari suatu sistem penjualan adalah sebagai berikut:

1. Surat Contoh Barang.

2. Surat Permintaan Barang.

3. Surat Hasil Pengecekan Barang.

4. Surat Permintaan Pengiriman Barang.

5. Surat Pengiriman Barang.

6. Surat Kesepakatan Pembayaran.

Bagian-bagian yang terkait dengan proses penjualan adalah:

1. Konsumen.

2. Gudang.

3. Pimpinan.

Bagian-bagian yang terkait dalam proses penjualan memiliki job description masing-masing yang dapat diuraikan sebagai berikut:

\section{Konsumen}

- Menikmati hasil barang atau produk dari perusahaan yang dapat memenuhi kebutuhannya ataupun keinginannya.

- Memesan barang atau produk yang dihasilkan perusahaan sesuai dengan kebutuhannya.

\section{Gudang}

- Melakukan perhitungan stok barang setiap minggu dan melakukan penyesuaian persediaan.

- Menyediakan barang pesanan pelanggan berdasarkan pemesanan penjualan.

- Menghitung dan mencatat barang yang dikirim dari pemasok. 


\section{Pimpinan/manajer}

- Membantu direktur untuk menentukan kebijakan baik kebijakan jangka pendek ataupun jangka panjang, mengawasi kegiatan operasional perusahaan sesuai dengan standar perusahaan, dan menerima laporan dari bagian gudang.

Salah satu aspek yang ada dalam penjualan adalah penjualan dengan sistem tatap muka (face-to-face selling), di mana seorang penjual langsung berhadapan muka dengan calon pembelinya. Masalah tersebut menjadi titik berat dalam pembahasan tentang proses penjualan berikut. Adapun tahap-tahapnya adalah seperti berikut ini:

1. Persiapan Sebelum Penjualan

Kegiatan yang dilakukan adalah mempersiapkan tenaga penjualan dengan memberikan pengertian tentang barang yang dijualnya, pasar yang dituju, dan teknik-teknik penjualan yang harus dilakukan. Selain itu, perusahaan juga lebih dulu harus mengetahui kemungkinan tentang motivasi dan perilaku dalam segmen pasar yang dituju.

2. Penentuan Lokasi Pembeli Potensial

Data pembeli yang lalu maupun sekarang seharusnya disimpan dengan rapi, sehingga memungkinkan perusahaan dapat menentukan karakteristiknya, misalnya lokasi. Oleh karena itu, pada tahap kedua ini ditentukan lokasi dari segmen pasar yang menjadi sasarannya. Dari lokasi ini dapatlah dibuat sebuah daftar tentang orang-orang atau perusahaan yang secara logis merupakan pembeli potesial dari produk yang ditawarkan. Dari konsumen yang ada dapat pula ditentukan konsumen manakah yang sudah menggunakan produk-produk saingan.

3. Pendekatan Pendahuluan

Sebelum terjadinya proses jual beli, perusahaan harus mempelajari semua masalah tentang individu atau perusahaan yang dapat diharapkan sebagai pembelinya. Selain itu, perlu juga mengetahui tentang produk atau merk apa yang sedang mereka gunakan dan bagaimana reaksinya. Berbagai macam informasi perlu dikumpulkan untuk mendukung penawaran produknya kepada pembeli, misalnya tentang kebiasaan membeli, kesukaan, dan sebagainya. Semua kegiatan ini dilakukan sebagai pendekatan pendahuluan terhadap pasarnya.

4. Melakukan Penjualan

Penjualan yang dilakukan bermula dari suatu usaha untuk memikat perhatian calon konsumen, kemudian diusahakan untuk mengetahui daya tarik mereka, dan akhirnya penjual melakukan penjualan produknya kepada pembeli.

5. Pelayanan Purna Jual

Kegiatan penjualan tidak berakhir pada saat pesanan dari pembeli telah dipenuhi, tetapi masih perlu dilanjutkan dengan memberikan pelayanan atau servis kepada mereka. Biasanya kegiatan ini dilakukan untuk penjualan barangbarang industri, seperti instalasi atau barang konsumsi tahan lama seperti almari es, televisi, dan sebagainya. Beberapa pelayanan yang diberikan oleh penjual sesudah penjualan dilakukan antara lain berupa:

a. Pemberian garansi. 
b. Pemberian jasa reparasi.

c. Latihan tenaga-tenaga operasi dan cara penggunaannya.

d. Penghantaran barang ke rumah.

Dalam tahap terakhir ini penjual harus berusaha mengatasi berbagai macam keluhan atau tanggapan yang kurang baik dari pembeli. Pelayanan lain yang juga perlu diberikan sesudah penjualan adalah memberikan jaminan kepada pembeli bahwa keputusan yang diambilnya tepat, barang yang dibelinya betulbetul bermanfaat, dan hasil kerja produk tersebut memuaskan.

\section{METODE PENELITIAN}

\section{Pendekatan Penelitian}

Jenis penelitian yang digunakan adalah pendekatan kualitatif deskriptif yang menggunakan data berupa kalimat lisan atau tertulis, perilaku, fenomena, peristiwa-peristiwa, pengetahuan, dan objek studi untuk memperoleh deskripsi yang lengkap dan akurat mengenai penerapan teknologi informasi dalam mendukung aktivitas penjualan pada perusahaan percetakan Excellent di Surabaya.

\section{Rancangan Penelitian}

Menurut Moleong (2000: 236), rancangan penelitian diartikan sebagai usaha merencanakan dan menentukan segala kemungkinan dan perlengkapan yang diperlukan dalam suatu penelitian kualitatif. Tujuan pokok dari desain penelitian adalah membantu peneliti menghindari data yang tidak mengarah dan menyiapkan pertanyaan sebagai awal penelitian. Sesuai dengan penentuan rumusan masalah, yang menjadi fokus utama peneliti yaitu: penerapan teknologi informasi untuk mendukung aktivitas penjualan pada perusahaan percetakan Excellent di Surabaya.

\section{Prosedur pengumpulan data}

Prosedur yang digunakan dalam rangka pengumpulan data untuk penelitian ini adalah sebagai berikut:

1. Observasi

Observasi dilakukan untuk memperoleh data yang berkaitan dengan aktivitas penjualan.

2. Dokumentasi

Dokumentasi merupakan prosedur yang dilakukan dalam rangka mengumpulkan data mengenai:

a) Profil umum perusahaan.

b) Gambaran tentang aktivitas penjualan.

c) Wawancara yang dilakukan dengan pimpinan perusahaan.

\section{Teknik Analisis}

Teknik analisis merupakan teknik untuk menelaah seluruh data yang tersedia dari berbagai sumber, yaitu dari observasi, dokumentasi, dan wawancara untuk menjamin keakuratan dan keabsahan data yang diperoleh. Data dari hasil penelitian selanjutnya diolah dan dianalisis secara deskriptif dengan pendekatan 
kualitatif sebagai berikut:

1. Mengidentifikasi data yang terkumpul.

2. Melakukan analisis deskriptif kualitatif untuk menganalisis manfaat teknologi informasi untuk mendukung aktivitas penjualan.

3. Menarik suatu simpulan dari hasil analisis yang dilakukan serta memberikan saran kepada pimpinan perusahaan untuk mendukung adanya continous improvement.

\section{PEMBAHASAN}

Perusahaan percetakan Excellent di Surabaya merupakan perusahaan percetakan digital. Agar bisa bersaing dengan perusahaan percetakan lainnya, maka perkembangan teknologi percetakan harus diikuti terutama berkaitan dengan sistem informasinya. Pada transaksi penjualan online terdapat server yang dalam hal ini berfungsi sebagai kotak surat elektronik untuk membantu dalam memesan pesanan yang diinginkan. Jenis server yang dipakai adalah commerce server yang berhubungan langsung dengan perdagangan, yang meliputi:

1. Dukungan untuk protokol secure electronic transaction yang melibatkan pembacaan kode semua komunikasi antara penjual dan pelanggan untuk memastikan bahwa transaksi bersifat pribadi.

2. Dukungan yang diperlukan untuk pelanggan khusus dengan penggunaan sertifikat digital untuk meyakinkan identitas pelanggan.

3. Dukungan yang memungkinkan pelanggan untuk mengakses informasi mengenai cara pemesanan, cara pembayaran, dan biaya pengiriman.

4. Tampilan katalog produk yang ditawarkan, informasi kartu kredit untuk pembayaran yang menggunakan kartu kredit, informasi mengenai pengiriman pesanan.

5. Verifikasi online kartu kredit.

Alur penjualan di perusahaan percetakan Excellent terlihat seperti bagan pada Gambar 2 dengan penjelasan sebagai berikut:

1. Pelanggan memesan produk cetakan yang diinginkan secara online sesuai spesifikasi keinginan pelanggan.

2. Bagian penjualan dan marketing menerima pesanan penjualan dan memproses sesuai pesanan yang diinginkan pelanggan.

3. Setelah selesai memproses, maka pesanan produk akan dikirim ke pelanggan, juga ada yang dikirim berupa software.

4. Setelah diterima dan diverifikasi, pelanggan dapat membayar secara tunai dengan transfer bank yang ditetapkan sebelumnya ataupun secara kredit.

5. Bagian penjualan mengonfirmasi setelah dana pembayaran benar-benar telah diterima. 


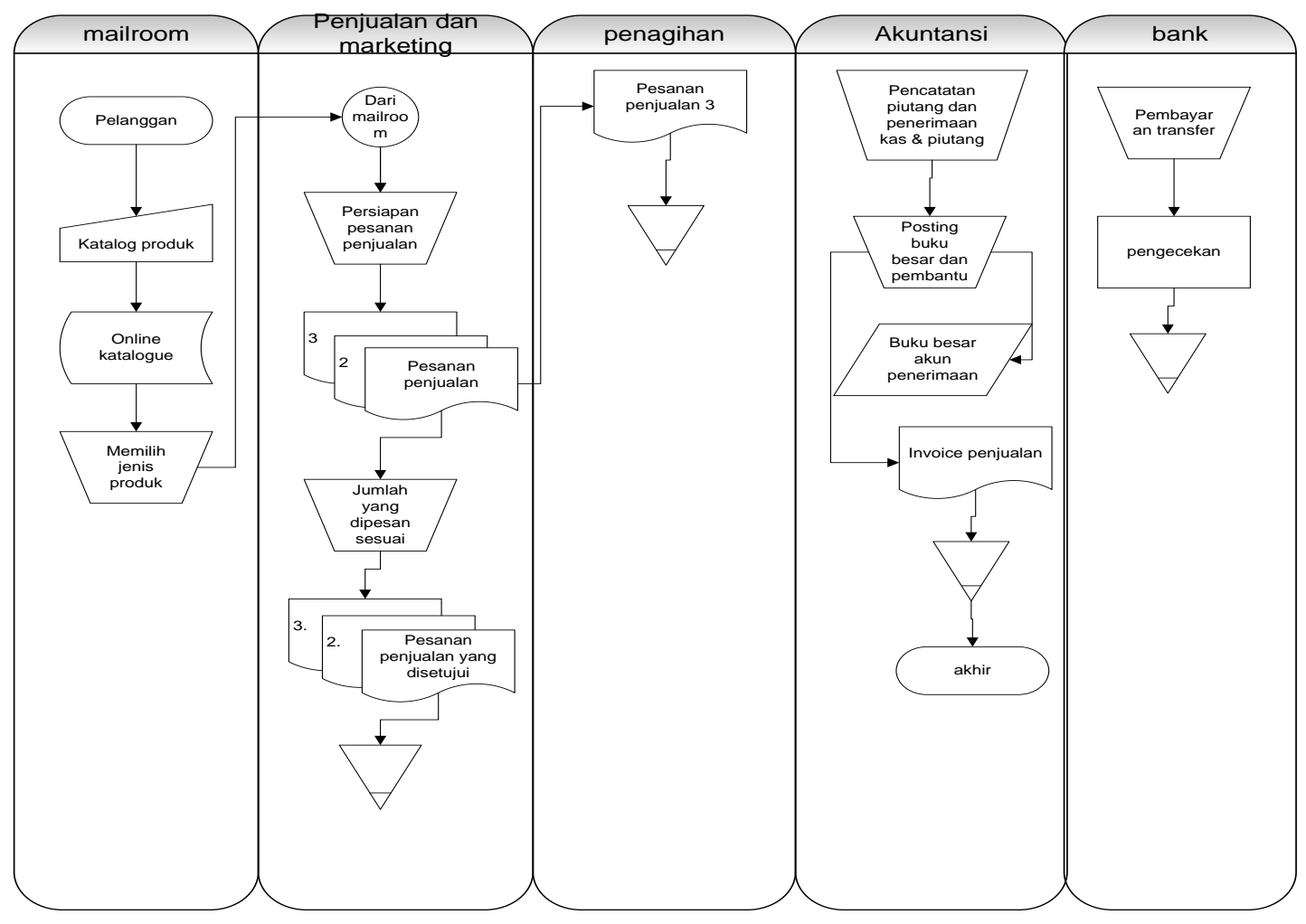

Gambar 2

Diagram Flowchart Perusahaan Percetakan Excellent

\section{SIMPULAN}

Pelaksanaan aktivitas penjualan online di perusahaan percetakan Excellent sudah berjalan dengan baik, di mana sistem pembayaran secara tunai dan kredit juga dinilai sudah memadai. Pembagian tugas juga sudah dilakukan dengan baik. Namun pelaporan oleh bagian akuntansi kepada pimpinan mengenai penjualan per pesanan sering terlambat.

\section{SARAN}

Pelaporan hasil penjualan harus dapat dilakukan secara tepat waktu. Untuk itu perusahaan perlu melakukan investasi teknologi mengingat kebutuhan akan teknologi meningkat. Bagian pemasaran hendaknya lebih aktif melakukan promosi, mengingat banyaknya pesaing. Demikian pula komunikasi yang efektif dan terus menerus harus selalu dijalankan terutama dengan konsumen yang loyal.

\section{DAFTAR PUSTAKA}

Baridwan, Zaki, 2013, Sistem Informasi Akuntansi, Edisi 2, Cetakan ke-8, BPFE, Yogyakarta.

Efraim, Turban, Dorothy Leidner, Ephraim McLean, and James Wetherbe, 2005, Information Technology for Management: Transforming Organization in The Digital Economy, 5th Edition, John Wiley \& sons, Inc. USA 
Hall, James A., 2013, Sistem Informasi Akuntansi, Edisi 9, Terjemahan, Salemba Empat, Jakarta.

Jogiyanto, H. M., 2002, Sistem Informasi Akuntansi Berbasis Komputer, Edisi II, BPFE, Yogyakarta.

Kadir, A., 2003, Dasar Aplikasi Database MySQL Delphi, Penerbit Andi, Yogyakarta .

Krismiaji, 2015, Sistim Informasi Akuntansi, Edisi 4, YKPN, Yogyakarta.

Laudon, Kenneth C. and Jane P. Laudon, 2014, Management Information Systems, Thirteenth Edition, Pearson Education Limited, England.

Moleong, Lexy J., 2000, Metodologi Penelitian Kualitatif, Edisi Sebelas, PT Remaja Rosada Karya, Bandung.

Mulyadi, 2013, Sistem Akuntansi, Edisi 3, Salemba Empat, Jakarta.

Parker, C. S., 1989, Management Information System, Srategy and Action, McGrawllhill, Singapore.

Putranta, Hastha Dewa, 2004, Pengantar Sistem dan Teknologi Informasi, AMUS, Yogyakarta.

Steinbert, M. R., 2003, Sistem Informasi Akuntansi, Salemba Empat, Jakarta.

Subiakto, Henri, 2016, Transformasi Teknologi Komunikasi Digital Terhadap Perubahan Sosial Sebagai Persoalan Aktual, Universitas Airlangga, Surabaya. 